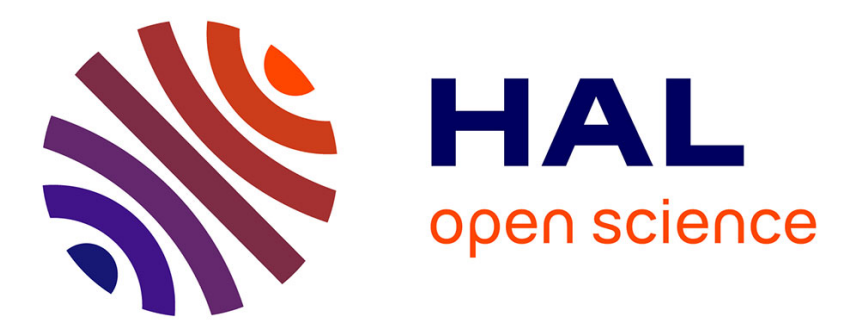

\title{
A detailed study of snow accumulation and stable isotope content in Dome C (Antarctica)
}

J. Petit, Jean Jouzel, M. Pourchet, Liliane Merlivat

\section{To cite this version:}

J. Petit, Jean Jouzel, M. Pourchet, Liliane Merlivat. A detailed study of snow accumulation and stable isotope content in Dome C (Antarctica). Journal of Geophysical Research, 1982, 87 (C6), pp.4301-4308. 10.1029/JC087iC06p04301 . hal-03482827

\section{HAL Id: hal-03482827 \\ https://hal.science/hal-03482827}

Submitted on 5 Jan 2022

HAL is a multi-disciplinary open access archive for the deposit and dissemination of scientific research documents, whether they are published or not. The documents may come from teaching and research institutions in France or abroad, or from public or private research centers.
L'archive ouverte pluridisciplinaire HAL, est destinée au dépôt et à la diffusion de documents scientifiques de niveau recherche, publiés ou non, émanant des établissements d'enseignement et de recherche français ou étrangers, des laboratoires publics ou privés. 


\title{
A Detailed Study of Snow Accumulation and Stable Isotope Content in Dome C (Antarctica)
}

\author{
J. R. Petit, ${ }^{1}$ J. Jouzel ${ }^{2}$ M. Pourchet, ${ }^{1}$ And L. Merlivat $^{2}$
}

\begin{abstract}
Snow samples have been taken in the Dome $\mathrm{C}$ area in order to study the variations of the accumulation rate and of the stable isotope content over the last century. Stake observations indicate a large spatial variability of the accumulation rate at a 1-year scale $\left(\sigma_{s}=2.6 \mathrm{~g} \mathrm{~cm}^{-2} \mathrm{yr}^{-1}\right.$ for a mean value $\left.\bar{a}=3.6 \mathrm{~g} \mathrm{~cm}^{-2} \mathrm{yr}^{-1}\right)$. The depth of the 1965 and 1955 layers determined from beta radioactivity measurements in 19 sites lets us deduce that the spatial variability becomes small at a 10-year scale ( $\sigma_{s}$ $=0.3 \mathrm{~g} \mathrm{~cm}^{-2} \mathrm{yr}^{-1}$ ), showing that the snow collected at one point is well representative of the fallen precipitation over this period. The rate of snow accumulation since 1965 is about $30 \%$ higher than during the 1955-1965 period. This conclusion is supported by measurements over a large geographical sector of East Antarctica. Shorter-term changes of the snow accumulation have been studied by various means and in particular from detailed deuterium content profiles; by comparing with the beta and tritium radioactivity determinations it is shown that the deuterium variations do not allow us to obtain a seasonal record. In such a low-accumulation area, different mechanisms (such as smoothing of the isotopic signal, roughness of the surface, irregularity of the accumulation) which may disturb the short-term record are discussed. The interpretation of stratigraphic observations is not straightforward. However, it was possible to obtain a calibration down to the 1955 layer, which allows us to offer a dating of the snow layers over the last century. The mean accumulation so obtained $\left(3.7 \mathrm{~g} \mathrm{~cm}^{-2} \mathrm{yr}^{-1}\right)$ is in good agreement with the value $(3.6 \pm 0.5)$ deduced from lead 210 measurements. Geographical changes of the mean deuterium content are relatively small, showing that at a 10-year scale the isotopic signal is well representative of the mean deuterium content of the precipitation. This ensures that the smoothed (10-year running mean values) deuterium profile obtained over the last 160 years provides a good indication of the temperature secular trend in the Dome $\mathrm{C}$ area.
\end{abstract}

\section{INTRODUCTION}

A very detailed study of snow accumulation and stable isotope content in the firn has been under way since 1975 in the Dome $\mathrm{C}$ area of Antarctica $\left(74^{\circ} 39^{\prime} \mathrm{S}, 124^{\circ} 10^{\prime} \mathrm{E}\right.$ (Figure 1)) where elevation is $3240 \mathrm{~m}$ above sea level and the mean temperature is $-53.5^{\circ}$. Our aim was to investigate the representativeness of these parameters on the scale of 10 100 years at that location intended for deep core drilling (905 $\mathrm{m})$, during the 1977-1978 Antarctic field season [Lorius et al., 1979] for paleoclimatological studies.

\section{SnOw Accumulation Rate}

Dome $\mathrm{C}$ is located in the central part of Antarctica where the snow accumulation rate (a) was expected to be very small (a few centimeters of snow per year) and difficult to determine precisely using only the classical method such as stake measurements and the visible stratigraphy studies [Koerner, 1971]. To get maximum information concerning the temporal and spatial variability of this parameter over the last century, we also applied other techniques such as artificial (gross $\beta$ and tritium) and natural (lead 210) radioactivity measurements and examination of detailed stable isotope profiles. For presentation purposes, we will divide these methods into three groups corresponding to increasing time scales:

1. The first group includes measurements made in the field during the three glaciological expeditions $(1975,1978$, and 1979), involving stake observations and surface roughness studies.

\footnotetext{
${ }^{1}$ Laboratoire de Glaciologie, Centre National de la Recherche Scientifique, 38031 Grenoble-Cedex, France.

${ }^{2}$ Département de Physico-chimie, Centre d'Etudes NucléairesSACLAY, 91190 Gif sur Yvette, France.
}

Copyright 1982 by the American Geophysical Union.
2. Over the 1955-1979 period, information was obtained from very detailed measurements of $\beta$ activity, tritium, and stable isotopes. The year 1955 corresponds to a very well defined reference level due to the first arrival of gross $\beta$ artificial radioactivity in Antarctica [Picciotto and Wilgain, 1963].

3. Before 1955 , only visible stratigraphy and lead 210 determinations could be used to deduce the accumulation rate.

\section{Field Observations (1975-1979)}

Seventy-eight stakes were placed around the Dome C station during the 1975 and 1978 expeditions, allowing accumulation rate determinations for 1-year and 4-year time intervals. For the 1-year period (58 measurements) the mean value was equal to $3.6 \pm 0.4 \mathrm{~g} \mathrm{~cm}^{-2} \mathrm{yr}^{-1}$ with a variability between the individual points of $2.6 \mathrm{~g} \mathrm{~cm}^{-2} \mathrm{yr}^{-1}$ (one standard deviation: $\sigma$ ). Among these observations there are 6 cases $(10 \%)$ with no accumulation or ablation and a total of 13 cases $(22 \%)$ with accumulations of less than half the mean annual value. In addition, detailed snow level studies have been performed on a $100-\mathrm{m}^{2}$ area (Figure 2) showing that the mean surface level variation (roughness) is equal to $10 \mathrm{~cm}$ or $4 \mathrm{~g} \mathrm{~cm}^{-2}$ of equivalent water. This relatively high surface relief is due to the removal of snow by wind leading to a value of the same order as the mean annual accumulation rate. It appears that stake measurements and surface level observations are quite consistent and clearly indicate that in the Dome $\mathrm{C}$ area, snow deposited at a single point cannot be considered to be representative of the snow precipitation on the 1-year scale.

For the 4-year period ( 25 observations) we obtained the same mean value $\left(a=3.8 \pm 0.15 \mathrm{~g} \mathrm{~cm}^{-2} \mathrm{yr}^{-1}\right)$ but a much lower variability between individual points $\left(0.8 \mathrm{~g} \mathrm{~cm}^{-2}\right.$ $\mathrm{yr}^{-1}$ ), demonstrating, as would be expected, that successive 


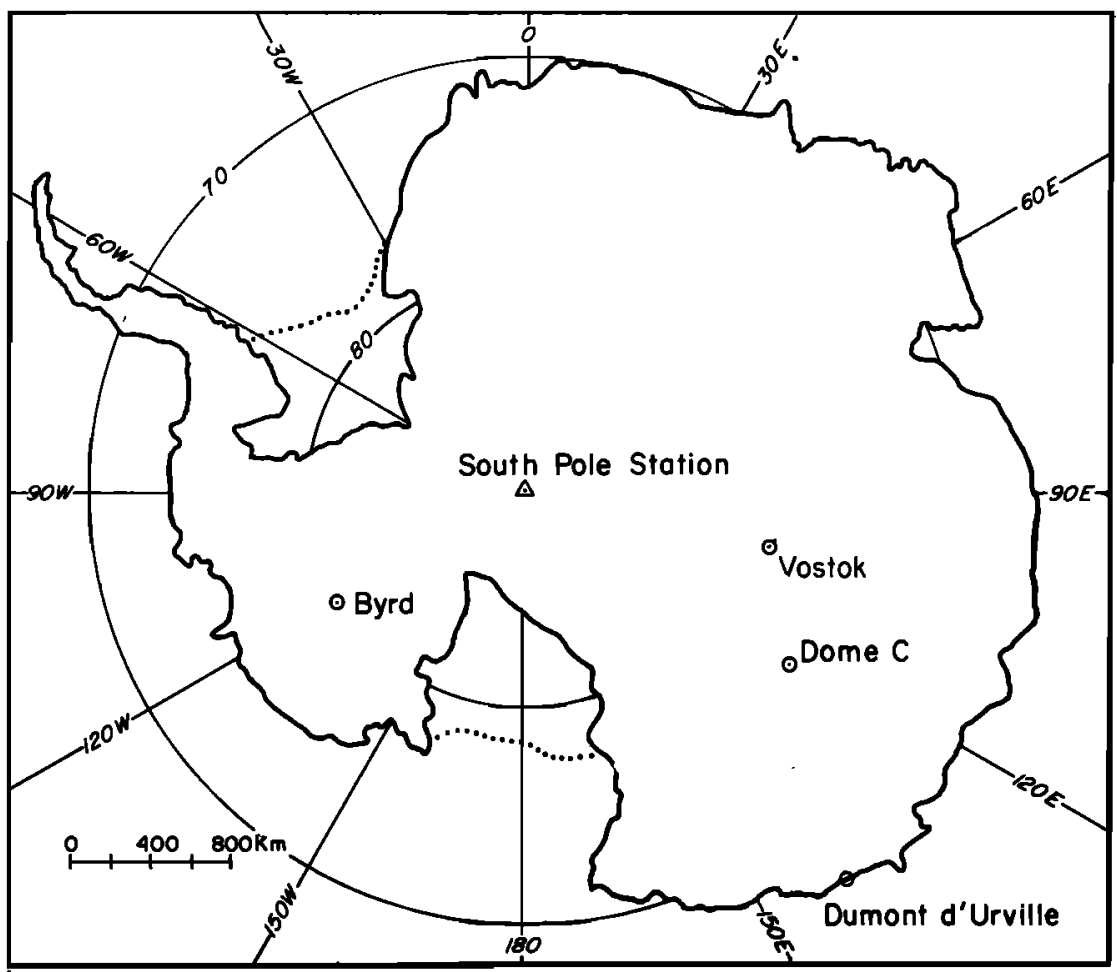

Fig. 1. Map of Antarctica.

annual rates at a given point are not independent variables. This is due to the fact that the mean surface roughness tends to be conserved, implying a preferential deposition of snow at low-level points. However, the low variability observed indicates that accumulated snow is quite representative of the precipitation of a 4-year scale.

\section{Period From 1955 to 1975}

The $\beta$ radioactivity measurements. The values of artificial $\beta$ activity in Antarctic snow are characterized by two well-defined reference levels, one, previously mentioned, at the beginning of 1955 [Picciotto and Wilgain, 1963] and the other from the end of 1964 to the beginning of 1965 [Crozaz,
1969] due to the arrival in the Antarctic area of radioactive debris from the Castle series in 1954 and from the 1962-1963 nuclear tests, respectively. In addition, a basic feature of the $\beta$ activity fallout in the southern hemisphere is the appearance of a broad summer maximum and winter minimum. This seasonal pattern, connected to the stratospheric-tropospheric exchange mechanisms, has been observed in southern hemisphere precipitation [Taylor, 1968] and in the South Pole $\beta$ profile, providing additional information concerning the snow deposition chronology at this station [Jouzel et al., 1979].

In the present Dome $\mathrm{C}$ study, a new method based on the use of ion exchange filters was applied [Delmas and Pour-

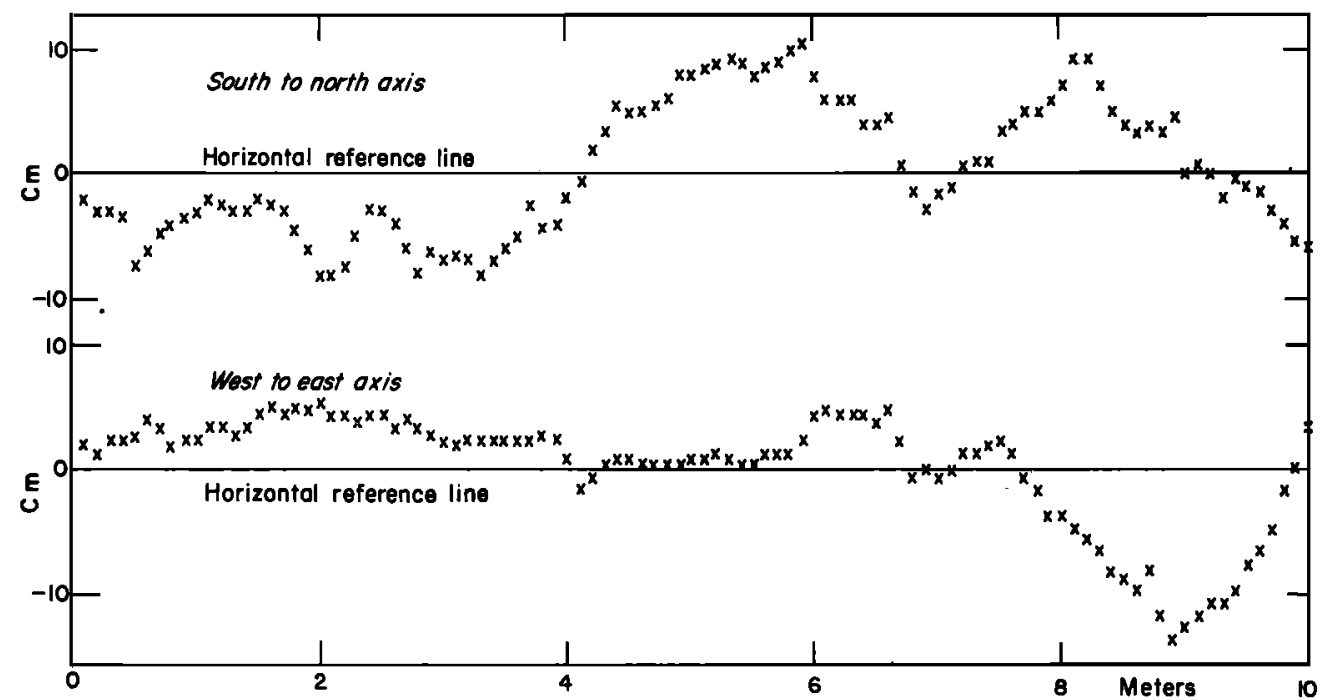

Fig. 2. Example of level variation of the snow surface versus an artificial horizontal line in two right angle directions at the Dome $\mathrm{C}$ area. 


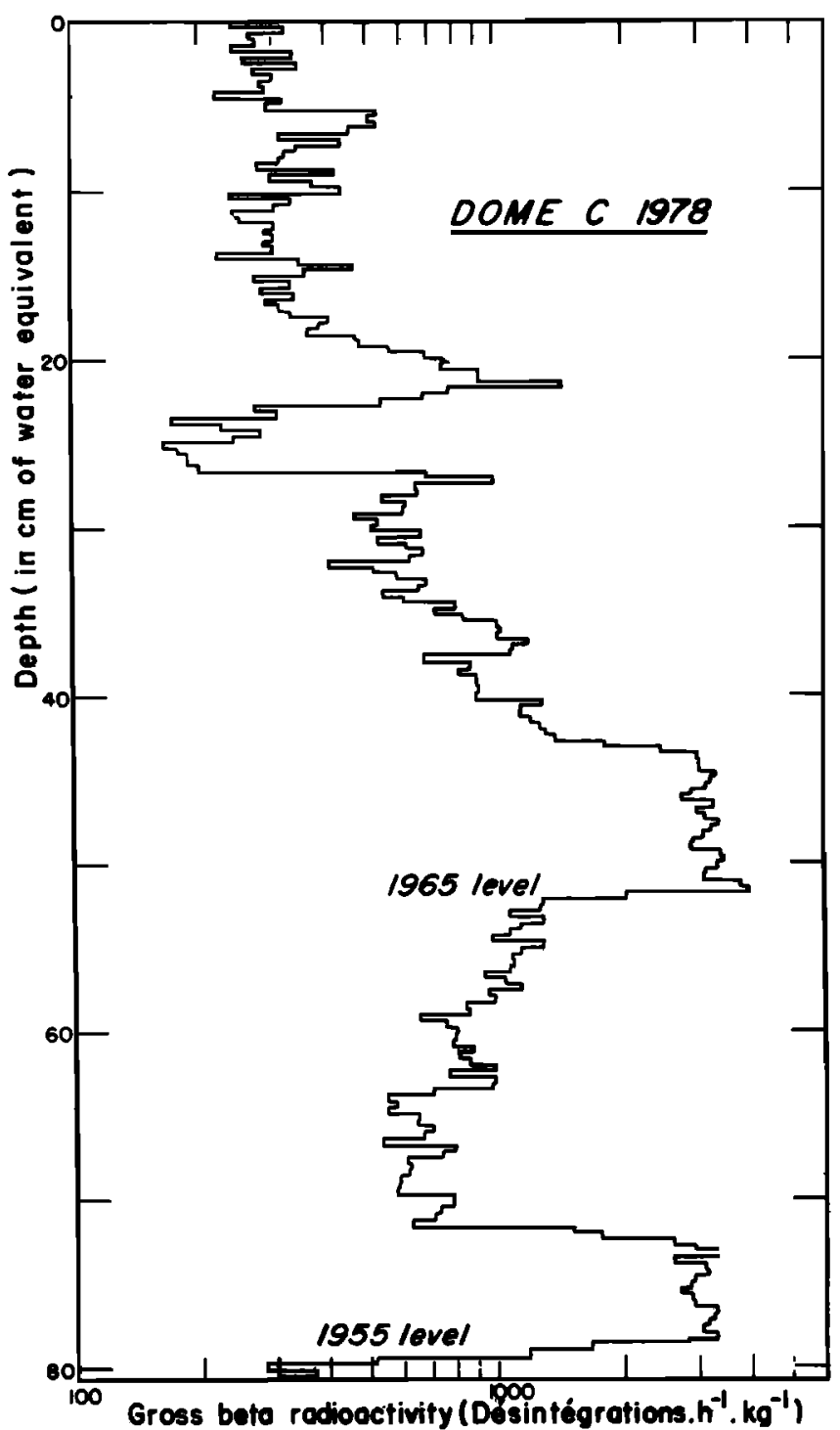

Fig. 3. Profile of total beta radioactivity of filtered ice core samples from Dome $\mathrm{C}$ area.

chet, 1977], allowing the preparation of a large number of samples in the field. A total of 1660 samples, taken at 19 different sites, were analyzed. Seventeen of these sampling points are located in a $20-\mathrm{km}^{2}$ area centered at the station, and the two others are 25 and $98 \mathrm{~km}$ away, respectively. Figure 3 shows one of the profiles obtained, with two wellmarked peaks, that can be used to fix precisely the 1955 and 1965 reference levels. However, successive $\beta$ summer maximum are not clearly displayed and cannot be used for additional annual chronology. The reported profile is very typical, the 1955 and 1965 levels being easily detectable in each of the 19 studied cases and the seasonal pattern being largely obliterated. This last problem, concerning the disappearance of seasonal variations, is discussed at the end of this section.

The chronological information deduced from these extensive studies of $\beta$ activity is reported in Table 1 . For the accumulation rate, a single cumulative density $(d)$ curve, obtained by plotting different sets of density measurements versus depth, has been used. It can be expressed by

$$
d=0.345+6.4 \times 10^{-3} z
$$

where $z$ is the depth in meters. The mean annual accumulation rate was calculated over three distinct periods, from 1955 to 1965 , from 1965 to the sampling date, and from 1955 to the sampling date (Table 1).

The experimental error $\left( \pm \sigma_{e}\right)$ for the 10-year and 20-year periods is estimated to be \pm 0.3 and $\pm 0.2 \mathrm{~g} \mathrm{~cm}^{-2} \mathrm{yr}^{-1}$, respectively, taking into account the different sources of error concerning the density determination and the sampling procedure. The $\beta$ arrival dates (taken as January 1955 and January 1965) appear to be well defined in Antarctica [Picciotto and Wilgain, 1963; Crozaz, 1969], and even a 2month shift, due, for example, to the different tropospheric behavior of the $\beta$ aerosol in the Dome $C$ area as compared to other parts of Antarctica, does not appreciably modify this estimated error.

Two interesting pieces of information concerning the spatial and temporal variation of the accumulation rate in the Dome $\mathrm{C}$ area can be derived from these data (Table 1).

If we consider the two successive decades, the total variability of the individual results $\left(\sigma_{T}\right)$ is equal to 0.35 and $0.45 \mathrm{~g} \mathrm{~cm}^{-2} \mathrm{yr}^{-1}$, respectively, excluding site 17 , located 98 $\mathrm{km}$ away from the main Dome $\mathrm{C}$ camp, where the accumulation rate is significantly higher than near the station. This parameter $\sigma_{T}$ is linked to the measurement error $\sigma_{e}$ and to the spatial variability $\sigma_{s}$ by $\sigma_{T}{ }^{2}=\sigma_{s}{ }^{2}+\sigma_{e}{ }^{2}$. From this we deduce that $\sigma_{s}$ is equal to $0.3 \mathrm{~g} \mathrm{~cm}^{-2} \mathrm{yr}^{-1}$ (taking 0.4 as a mean value for $\left.\sigma_{T}\right)$. Therefore the spatial variability observed on the annual signal $\left(2.6 \mathrm{~g} \mathrm{~cm}^{-2} \mathrm{yr}^{-1}\right)$ becomes very weak on a 10-year scale. This indicates that the snow collected at a point is quite representative of the Dome $\mathrm{C}$ area and consequently of the precipitation fallen during the considered period, this last point being very important for climatological and paleoclimatological studies. As would be expected, the weakness of spatial variability is also verified for the 20-year scale, $\sigma_{s}$ being equal to $0.2 \mathrm{~g} \mathrm{~cm}^{-2} \mathrm{yr}^{-1}$ (with $\sigma_{T}=0.3 \mathrm{~g} \mathrm{~cm}^{-2} \mathrm{yr}^{-1}$ and $\left.\sigma_{e}=0.2 \mathrm{~g} \mathrm{~cm}^{-2} \mathrm{yr}^{-1}\right)$. This indicates that the site chosen for the drilling of the $905-\mathrm{m}$ deep core can be considered as being well representative of this region.

A significant increase in the mean accumulation rate between the two successive decades, from $2.7 \pm 0.1 \mathrm{~g} \mathrm{~cm}^{-2}$ $\mathrm{yr}^{-1}(1955-1965)$ to $3.5 \pm 0.1 \mathrm{~g} \mathrm{~cm}^{-2} \mathrm{yr}^{-1}$ (after 1965), is also evident in Table 1 . This striking feature, previously observed by Lambert et al [1978] and Pourchet et al. [1979], over a large part of Antarctica, has not been satisfactorily explained. We will see below that the accumulation variability for 10-year periods over last 100 years is equal to $0.8 \mathrm{~g} \mathrm{~cm}^{-2}$ $\mathrm{yr}^{-1}$ at Dome $\mathrm{C}$, showing that, at least at this station, the $30 \%$ increase between the two successive decades can be considered normal.

Tritium measurements. As previously shown by many authors [Merlivat et al., 1977; Jouzel et al., 1979], tritium measurements are a valuable dating tool for the last 20 years, based on the existence of several reference levels and of a seasonal pattern. A well-dated profile measured at the South Pole [Jouzel et al., 1979] allowed us to define the main features of tritium fallout in Antarctica, characterized by its first arrival in 1954, maximum values in 1960, 1966, 1969, and 1973, and low values in 1961 and 1962, all these levels being highly related to nuclear explosions (except for the 1973 level). Each annual tritium peak clearly appears during the Antarctic winter, indicating different injection mecha- 
TABLE 1. Accumulation Rates From Total Beta Radioactivity Measurements, at 19 Different Sites in the Dome C Area

\begin{tabular}{|c|c|c|c|c|c|c|c|}
\hline \multirow[b]{2}{*}{ Station } & \multirow[b]{2}{*}{ Sampling Date } & \multicolumn{2}{|c|}{$\begin{array}{c}\text { Depth of the } 1955 \text { and } 1965 \text { Beta } \\
\text { Level From the Sampling } \\
\text { Surface, cm }\end{array}$} & \multicolumn{3}{|c|}{ Accumulation Rate, $\mathrm{g} \mathrm{cm}^{-2} \mathrm{yr}^{-1}$} & \multirow{2}{*}{$\begin{array}{c}\text { Accumulation } \\
\text { Variation (in \%) } \\
\text { Between the Post- } \\
1965 \text { and the } 1955- \\
1965 \text { Periods }\end{array}$} \\
\hline & & $\begin{array}{c}\text { January } 1955 \\
\text { Beta Level }\end{array}$ & $\begin{array}{c}\text { January } 1965 \\
\text { Beta Level }\end{array}$ & $\begin{array}{l}1955-1965 \\
\text { Period }\end{array}$ & Since 1965 & Since 1955 & \\
\hline 1 & 1978 & 180 & 129 & 1.8 & 3.5 & 2.8 & 94 \\
\hline 2 & 1978 & 195 & 138 & 2.1 & 3.8 & 3.0 & 81 \\
\hline 3 & 1978 & 198 & 122 & 2.8 & 3.3 & 3.1 & 18 \\
\hline 4 & 1978 & 155 & 95 & 2.2 & 2.5 & 2.4 & 14 \\
\hline 5 & 1978 & 215 & 146 & 2.5 & 4.0 & 3.4 & 60 \\
\hline 6 & 1978 & 199 & 124 & 2.7 & 3.4 & 3.1 & 26 \\
\hline 7 & 1975 & 200 & 122 & 2.9 & 4.3 & 3.6 & 48 \\
\hline 8 & 1975 & 195 & 119 & 2.8 & 4.2 & 3.5 & 50 \\
\hline 9 & 1979 & 210 & 130 & 2.9 & 3.3 & 3.1 & 14 \\
\hline 10 & 1979 & 215 & 130 & 3.1 & 3.3 & 3.2 & 6 \\
\hline 11 & 1979 & 218 & 147 & 2.6 & 3.7 & 3.3 & 42 \\
\hline 12 & 1979 & 202 & 125 & 2.8 & 3.1 & 3.0 & 11 \\
\hline 13 & 1979 & 225 & 148 & 2.9 & 3.7 & 3.4 & 27 \\
\hline 14 & 1979 & 207 & 133 & 2.7 & 3.4 & 3.1 & 26 \\
\hline 15 & 1979 & 206 & 128 & 2.9 & 3.2 & 3.1 & 10 \\
\hline 16 & 1979 & 236 & 146 & 3.3 & 3.7 & 3.5 & 12 \\
\hline 17 & 1979 & & 194 & & 4.9 & & \\
\hline 18 & 1979 & 220 & 144 & 2.8 & 3.6 & 3.3 & 29 \\
\hline 19 & 1979 & 226 & 152 & 2.7 & 3.9 & 3.4 & 44 \\
\hline average & & & & 2.7 & 3.5 & 3.2 & 33 \\
\hline
\end{tabular}

All samples were taken in January.

nisms for $\beta$ and tritium and providing, in the case of the South Pole, a year to year dating method.

Four detailed tritium profiles have been obtained at Dome $\mathrm{C}$ in two different pits. Figure 4 shows one of these profiles covering the 1957-1971 period. On this curve the three reference levels corresponding to the 1960, 1966, and 1969 winter maxima can be easily attributed and agree well with the information previously deduced from the $\beta$ radioactivity measurements performed on the same samples (1955 and 1965 summer). However, the seasonal pattern is totally absent in spite of very extensive sampling (ten samples per year, on the average). The three other profiles are very similar, indicating clearly that tritium measurements cannot provide chronological information on the 1-year scale in the Dome $\mathrm{C}$ area. This agrees with the surface observations.

Deuterium measurements. Seasonal variations of deuterium content in the snow precipitation, with maximum and minimum occurring during summer and winter, respectively,

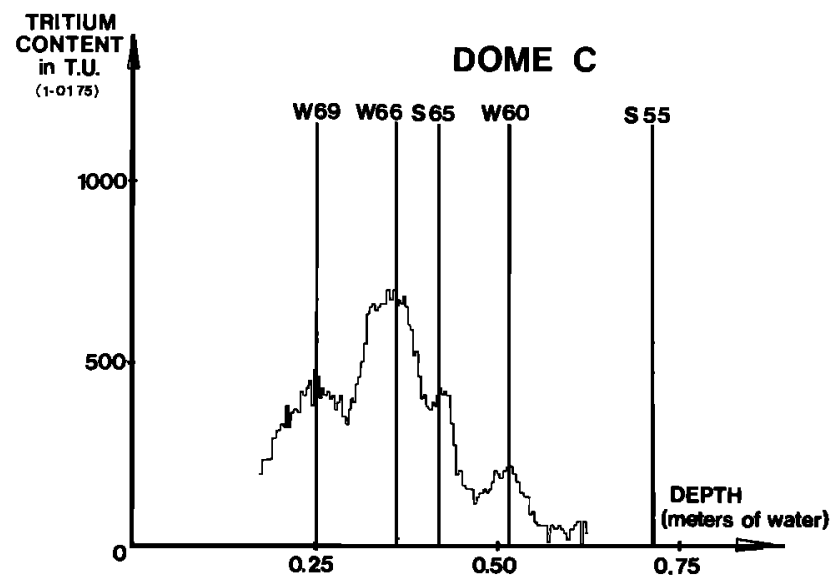

Fig. 4. Profile of artificial tritium content (in tritium units (T.U.)) measured in the Dome C snow. provide a widely used dating method [Hammer et al., 1978; Jouzel et al., 1979].

At Dome $\mathrm{C}$ we have obtained four deuterium profiles for the same samples as those measured for tritium. As shown in Figure 5, where we have reported $\beta$ and tritium chronology, there are fewer deuterium maxima than the estimated number of years in each dated interval, demonstrating that this deuterium profile cannot give any chronological information by itself. This point, so valuable for the other data sets, is consistent with the study previously carried out by Dansgaard et al. [1977] at Vostok (Antarctica), a station with a low accumulation rate $\left(a=4.4 \mathrm{~g} \mathrm{~cm}^{-2} \mathrm{yr}^{-1}\right)$.

Obliteration of seasonal variations. A common feature of the three described methods, based on the $\beta$ radioactivity, tritium, and deuterium analyses, is the general absence of

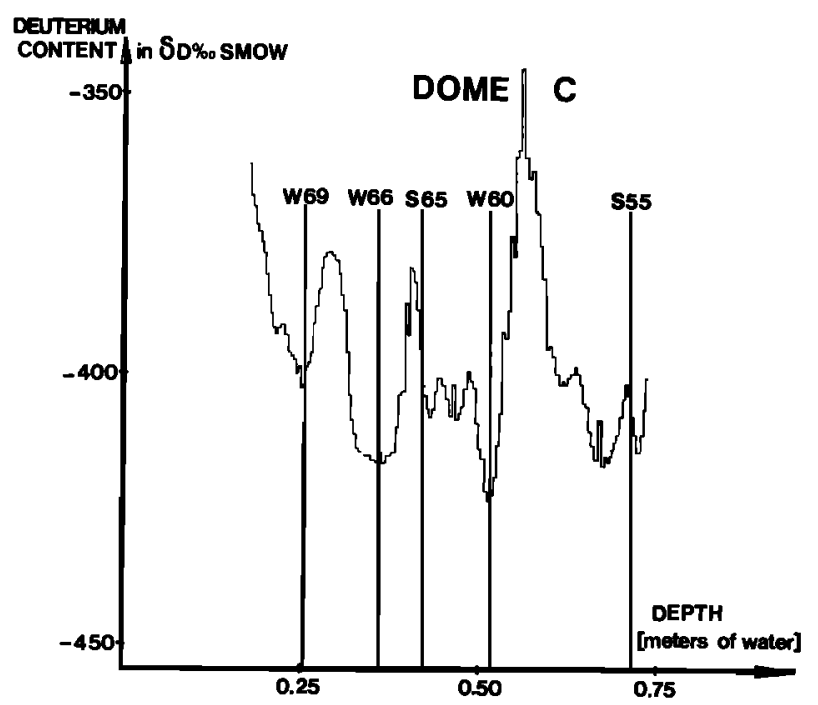

Fig. 5. Profile of deuterium content measured in the Dome $\mathrm{C}$ snow. 


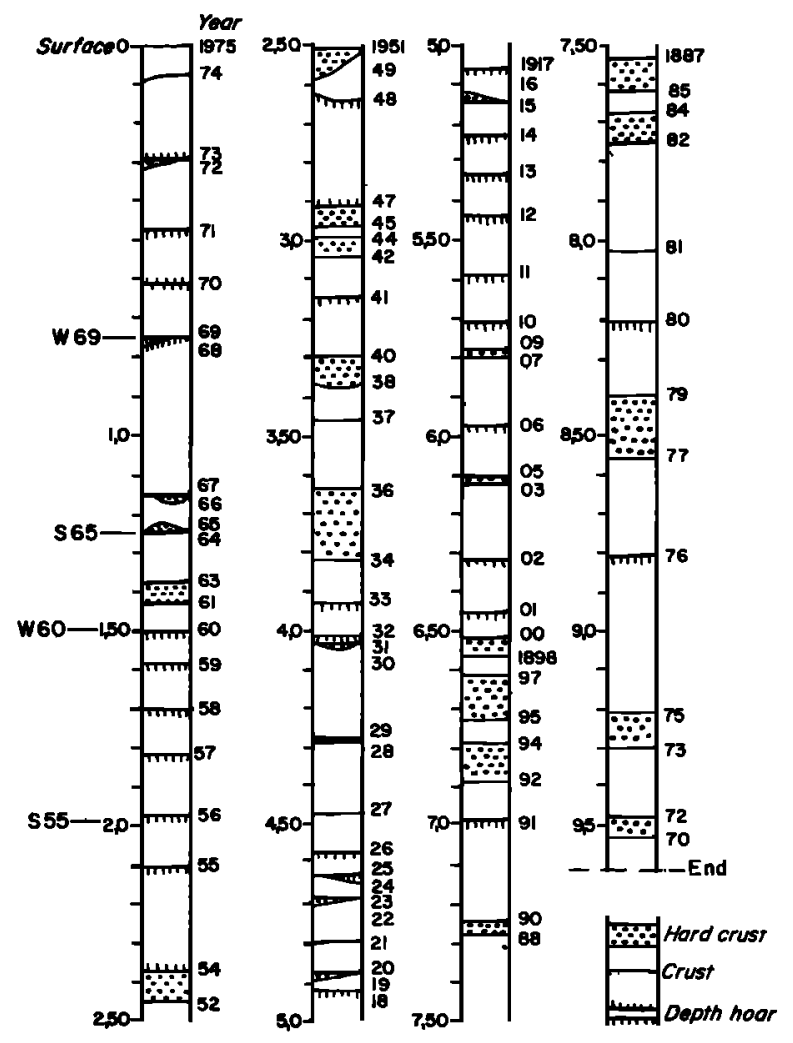

Fig. 6. Stratigraphy for 1975 made in the field from a pit wall (from the surface down to $5.34 \mathrm{~m}$ ) and continued by a stratigraphic core (from 5.34 down to $9.64 \mathrm{~m}$ ).

seasonal indexes. This can possibly be explained by three independent factors.

First, with such a low precipitation rate as observed in the Dome $\mathrm{C}$ area, the probability of the absence of precipitation during several months is not negligible. The Antarctic Plateau climate is characterized by a sharp transition between a long winter (April-September) and a short summer (December and January), so that the lack of precipitation during one of these two seasons always results in the missing of a year. In the absence of field observations, the probability of such an event is difficult to evaluate, but it could be an important factor.

Second, as shown by stake measurements, the removal processes in the surface snow layers are very important on the 1-year scale. It can reasonably be assumed that the probability of no snow accumulation at any one point of an area, during a given period, is equal to the percentage of this area showing no accumulation during the same period [Koerner, 1971]. In $22 \%$ of the cases studied, the accumulation was equal to or less than half of the mean annual value, resulting almost certainly in the disappearance of a seasonal index. With the available data, this figure is the best estimation of the annual signals which disappear in a $\beta$, tritium, or deuterium profile owing to removal processes due to the transport and deposition of snow by the wind.

Third, diffusion of the water molecules in the firn may be responsible for the smoothing of the $\mathrm{HDO}, \mathrm{H}_{2}{ }^{18} \mathrm{O}$, or HTO signal recorded in the new fallen snow, during the firnification [Johnsen, 1977]. In low-accumulation areas (less than 20 $\mathrm{g} \mathrm{cm}^{-2} \mathrm{yr}^{-1}$ ) the obliteration of seasonal isotopic variations would occur over a few decades. Recent results obtained at the South Pole for the last 25 years (mean accumulation rate equal to $8.2 \mathrm{~g} \mathrm{~cm}^{-2} \mathrm{yr}^{-1}$ ) indicate that this smoothing effect is less rapid than expected [Jouzel et al., 1979]. This phenomenon may affect the deuterium and tritium Dome C profiles over the last 20-year period; however, we were unable to calculate its relative influence with respect to the two other processes given as explanations for the obliteration of these seasonal isotope variations.

\section{Period Prior to 1955}

Stratigraphy. Stratigraphic studies represent a widely used dating tool based on the stratification of snow layers during the annual cycle [e.g., Gow, 1965] giving very reliable results even in low-accumulation areas such as the South Pole [Jouzel et al., 1979]. However, the application of this method is not obvious for very low accumulations as shown in a detailed study carried out by Koerner [1971] at Plateau Station and during the South Pole-Queen Maud Land Traverse (mean accumulation less than or equal to $4.4 \mathrm{~g} \mathrm{~cm}^{-2}$ $\mathrm{yr}^{-1}$ [Picciotto et al., 1971]). This study and our previous results showing the disappearance of seasonal indexes at Dome $\mathrm{C}$ indicate that difficulties may be encountered in applying the stratigraphic method in this area.

This can be confirmed by considering the results of N. I. Barkov in his field dating of a 9.54-m snow core. Barkov proposed a conventional interpretation based on the counting of summer hoar layers. Measurements of $\beta$ can be used to check on the obtained results, and we have found a loss of 5 years over the 1955-1975 period. Because of this difference in the results of the two methods, we tried to reinterpret the stratigraphic field observations made by Barkov, taking into account all the stratigraphic indexes corresponding to any physical change in the snow, i.e., the appearance of hoar layers, crust layers, hard layers, and so on.

The different layers which have already been accurately dated by $\beta$ and tritium measurements $(1955,1960,1965$, 1966, and 1969) were used to calibrate this new interpretation over a 20-year period. Within this zone, 14 stratigraphic indexes were observed, four of them being represented by a double-crust layer and another one by a 6-cm-thick hard layer. It was assumed that the double-crust layers correspond to 2 years of accumulation, which was supported by the general depletion of the adjacent layers (Figure 6). Following the interpretation proposed by Koerner [1971] at Plateau Station, we also attribute 2 years to the thick hard layer. With these two reasonable assumptions we get complete agreement between the previous dated levels and the stratigraphic interpretation.

This calibration justified the continued dating of the snow core down to $9.54 \mathrm{~m}$. A minimum value equal to 86 years, for the bottom age, was obtained by counting only the classical stratigraphic indexes $\left(a=4.4 \mathrm{~g} \mathrm{~cm}^{-2} \mathrm{yr}^{-1}\right)$. However, we observed very thick hard layers (up to $15 \mathrm{~cm}$ ), and a tentative estimate of the maximum age was made by assuming that they represent the number of years equal to the number of multiples of $3 \mathrm{~cm}$ included, a figure derived from the fact that the hard layer observed before 1955 , and very likely corresponding to 2 years, was $6 \mathrm{~cm}$ thick. This method gives a maximum age for the bottom of the core equal to 117 years $\left(a=3.3 \mathrm{~g} \mathrm{~cm}^{-2} \mathrm{yr}^{-1}\right)$.

Finally, we propose a more likely value (lying between these two extremes) which can be used to deduce a year to year dating. This value is determined by applying exactly the 
TABLE 2. Accumulation Rates Obtained From Different Methods

\begin{tabular}{clccc}
\hline Scale, years & Method & $\begin{array}{c}\text { Number of } \\
\text { Determinations }\end{array}$ & $\begin{array}{c}\text { Mean Value of } \\
\text { the Accumulation } \\
\text { Rate, } \mathbf{g ~ c m}^{-2} \mathbf{y r}^{-1}\end{array}$ & $\begin{array}{c}\text { Spatial } \\
\text { Variability, } \\
\mathbf{g ~ c m}^{-2} \mathbf{y r}^{-1}\end{array}$ \\
\hline 1 & stakes & 59 & $3.6 \pm 0.4$ & 2.6 \\
4 & stakes & 25 & $3.8 \pm 0.15$ & 0.8 \\
10 & $(1955-1965) \beta$ & 17 & $2.7 \pm 0.1$ & 0.3 \\
10 & $(1965-1975) \beta$ & 17 & $3.5 \pm 0.1$ & 0.3 \\
20 & $\beta$ & 17 & $3.2 \pm 0.1$ & 0.2 \\
100 & stratigraphy & 1 & 3.7 & \\
100 & $210 \mathrm{~Pb}$ & 1 & $3.6 \pm 0.5$ & \\
\hline
\end{tabular}

same criteria as those used for the calibration period (19551975), i.e., by attributing 2 years to each crust layer as well as to each thick hard layer. This leads to a bottom age of 105 years (Figure 6) corresponding to a mean accumulation of $3.7 \mathrm{~g} \mathrm{~cm}^{-2} \mathrm{yr}^{-1}$.

A slightly different approach can be taken by considering that high accumulation rates observed in the classical interpretation correspond to several years of accumulation. There are 11 years with annual accumulation rates higher than $8 \mathrm{~g} \mathrm{~cm}^{-2} \mathrm{yr}^{-1}$, the total thickness of which corresponds to 30 years of normal accumulation. This adds 19 additional years to the classical interpretation (86 years), supporting the 105 -year value previously proposed.

Lead 210 measurements. Measurement of the exponential decay with depth of the 20.4-year half-life $210 \mathrm{~Pb}$ concentration in the firn represents a method to deduce the mean annual accumulation rate on the 100 -year time scale, assuming that the $210 \mathrm{~Pb}$ concentration is constant in newly fallen snow [Sanak and Lambert, 1977]. Such a $210 \mathrm{~Pb}$ profile gives a $3.6 \pm 0.5 \mathrm{~g} \mathrm{~cm}^{-2} \mathrm{yr}^{-1}$ mean accumulation rate in close agreement with the 105-year dating deduced from stratigraphic studies.

\section{Summary of the Results Concerning the Accumulation Data}

Table 2 summarizes the values of accumulation rate obtained for different time scales and the estimation of the spatial variability when several determinations have been made over the same period. The decrease in spatial variability with increasing time scale is well illustrated by this table. For 1- to 10-year time scales, successive annual accumulation rates at a given point are clearly dependent ( $\sigma_{s}$ decreasing more quickly than the square root of the time scale). As has previously been pointed out, a 10-year period appears long enough to determine a representative value of the mean accumulation rate in the Dome $\mathrm{C}$ area.

At the 100-year scale, additional information can be deduced from the sulfate concentration profile determined for the same location [Delmas and Boutron, 1980], which shows a well-defined peak starting at a depth of $8.40 \mathrm{~m}$ from the snow surface. Such high sulfate values correspond to the signature of major volcanic events detected in deposited snow in Greenland [Hammer et al., 1978], as well as in Antarctica [Delmas and Boutron, 1980], for the Mont Agung eruption (1963), for example. In the studied case at Dome C the suggested volcanic event would be the 1883 Krakatoa eruption implying a $3.6 \mathrm{~g} \mathrm{~cm}^{-2} \mathrm{yr}^{-1}$ mean accumulation value, well in agreement with the lead 210 and the reinterpreted stratigraphic data (Table 2).

The consistency of the results obtained by the different methods gives a high level of confidence in the proposed stratigraphic interpretation, and we therefore attribute an age of 1870 years to the bottom of the core. This can now be used to deduce the temporal variation of the accumulation rate. For a 1-year scale (105 determinations) the variability is equal to $2.6 \mathrm{~g} \mathrm{~cm}^{-2} \mathrm{yr}^{-1}$, the same value as the spatial variability at this time scale (Table 2). Such a high agreement between spatial and temporal variability has already been observed at Byrd Station [Whillans, 1978], indicating that surface relief is fairly well preserved in the core stratigraphy. To present these results for a representative time scale, we have calculated the 10-year running mean values (Figure 7). This curve shows a rather high variability for this time scale, which can be attributed to snow precipitation variability. For the first nine successive decades this parameter is equal to $0.8 \mathrm{~g} \mathrm{~cm}^{-2} \mathrm{yr}^{-1}$. The high values observed at the bottom of the core were excluded from this calculation because stratigraphic observations were difficult in this lower part thereby increasing the probability of missing stratigraphic indexes.

The $3.6 \mathrm{~g} \mathrm{~cm}^{-2} \mathrm{yr}^{-1}$ mean annual value obtained for the studied snow core compares well with the mean value of 3.4 $\mathrm{g} \mathrm{cm}^{-2} \mathrm{yr}^{-1}$ calculated from the 905-m Dome $\mathrm{C}$ ice core for the last 10,550 years [Lorius et al., 1979], showing that the present-day accumulation rates are consistent with those of the last few thousands of years.

\section{STABle Isotope Contents}

The deuterium and oxygen 18 analyses of snow and ice samples are a very powerful tool in paleoclimatological

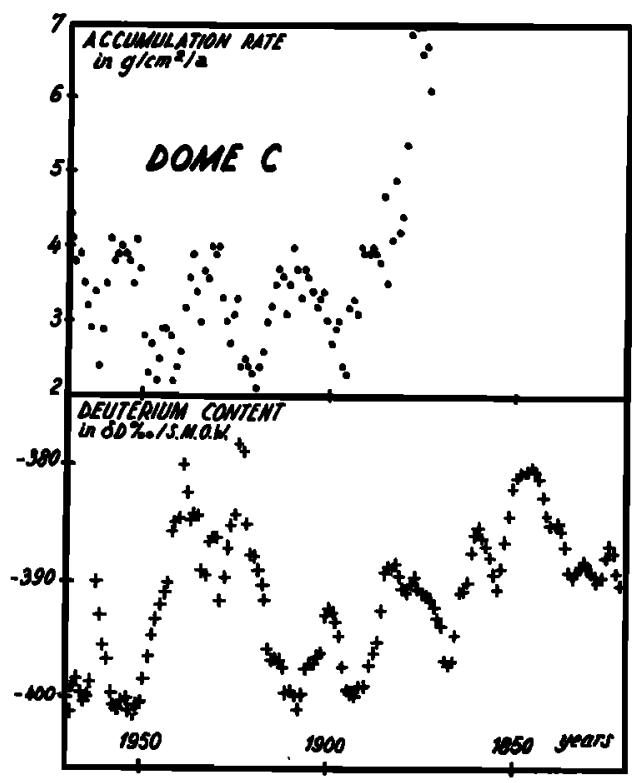

Fig. 7. Ten-year running mean of annual accumulation rate and deuterium content $\left(\mathrm{g} / \mathrm{cm}^{2} / \mathrm{a}\right.$ is $\left.\mathrm{g} \mathrm{cm}^{-2} \mathrm{yr}^{-1}\right)$. 
studies, the isotopic content of precipitation being dependent mainly on its temperature of formation [Dansgaard, 1964]. Basic features of the deuterium and ${ }^{18} \mathrm{O}$ distribution in ice caps are (1) the existence of seasonal variations providing a commonly accepted dating tool and (2) the dependence between the mean isotopic content and the mean annual temperature studied either at different sites over the same period [Lorius and Merlivat, 1977] or at a given site as a function of time which can be used in the reconstruction of past climatic conditions [Hammer et al., 1978; Lorius et al., 1979].

Our purpose in studying surface samples in the Dome $\mathrm{C}$ area was to determine the spatial variability of the isotopic signal and its temporal variation on the 100 -year time scale. We will present only the deuterium results (expressed in $\delta$ D\%o/SMOW), as the ${ }^{18} \mathrm{O}$ determinations were performed for only a part of the samples.

\section{Spatial Variability}

Twenty snow cores, each representing 13-15 years of accumulation, were sampled over a $25-\mathrm{km}^{2}$ area around the Dome $\mathrm{C}$ station. The mean deuterium content determined for the 20 results was $-387.5 \%$ with a standard deviation of $6 \%$. The spatial variability is actually even less than this value because each sample does not represent exactly the same period. This relatively low value shows that the isotopic signal measured in the firn is well representative of the mean isotopic content of the precipitation for this time scale.

\section{Hundred-Year Variations}

Deuterium analyses were performed on different sets of samples. We have obtained four detailed profiles covering the last 20 years (one of them is shown in Figure 5) and one less detailed profile (one sample per year on the average) with samples taken in a pit down to $5 \mathrm{~m}$ and from a core drilled in this pit from 5 down to $14 \mathrm{~m}$.

No attempt was made to correlate deuterium values with temperature records available in certain Antarctic locations over the last 20 years, as we have already seen that the snow sampled is not representative of the fallen precipitation on a 1-year scale. Thus an experimental determination of the temperature isotope gradient, as we made for the South Pole [Merlivat et al., 1979], is not possible for the Dome C area.

However, the 10-year running mean deuterium values shown in Figure 7 are well representative of the 100-year trend for the deuterium content in precipitation. Up to 1870 , this curve has been established by taking into account the previously determined annual accumulation rates, and from there down to the bottom of the core we have assumed a constant accumulation rate of $3.6 \mathrm{~g} \mathrm{~cm}^{-2} \mathrm{yr}^{-1}$.

This smoothed deuterium profile provides an indication of the 100-year trend of the temperature in the Dome $\mathrm{C}$ area over the last 160 years, showing two marked maxima over the 1830-1860 and 1920-1940 periods. The accumulation rates and deuterium variations do not appear to be correlated for the 1880-1970 period over which these two parameters have been determined.

\section{CONCLUSION}

From this very detailed study of snow surface samples taken in the Dome $\mathrm{C}$ area we can draw the following information:

1. In such low accumulation rate areas, the more powerful dating tools are those based on reference level determinations such as $\beta$ and tritium measurements, and to a lesser degree lead 210 and sulfate analyses. The disappearance of seasonal variations. ( $\beta$, deuterium, and tritium) prevents a highly reliable year to year dating. We have shown, however, that reinterpreted stratigraphic observations can provide such information even if it is less precise.

2. It is necessary to consider at least a 10-year period to obtain representative information concerning accumulation rates and stable isotope content. For this time scale, the spatial variability of these two parameters is sufficiently low to ensure that the profiles shown in Figure 7 represent a reliable record of the accumulation rates and 100-year temperature trends in the Dome $\mathrm{C}$ area.

Acknowledgments. We are grateful to N. I. Barkov and C. Lorius for the snow samples and the stratigraphy data during the first 1975 field season, to J. Palais for snow samples during the 1979 field season, and to Y. Gatter for his help in processing the snow samples. This work was supported by Terres Australes et Antarctiques Françaises, Expéditions Polaires Françaises and the U.S. National Science Foundation (Office of Polar Programs), and we gratefully acknowledge their field support and their assistance in making this study possible. Some of the snow samples were collected under a grant from the U.S. National Science Foundation (grant DPP 76-23428) awarded to I. M. Whillans of the Ohio State University. We thank C. Lorius for our helpful discussions.

\section{REFERENCES}

Crozaz, G., Fission product in Antarctic snow, An additional reference level in January 1965, Earth Planet. Sci. Lett., 6, 6-8, 1969.

Dansgaard, W., Stable isotopes in precipitation, Tellus, 16(4), 435468, 1964.

Dansgaard, W., N. I. Barkov, and J. Splettstoesser, Stable isotope variations in snow and ice at Vostok Antarctica, IAHS-AISH Publ., 118, 204-209, 1977.

Delmas, R., and C. Boutron, Are the past variations of stratospheric sulfate burden recorded in central Antarctic snow and ice layers?, J. Geophys. Res., 85, 5645-5649, 1980.

Delmas, R., and M. Pourchet, Utilisation de filtres échangeurs d'ions pour l'étude de l'activité Beta globale d'un carottage glaciologique, IAHS-AISH Publ., 118, 158-163, 1977.

Gow, A. J., On the accumulation and seasonal stratification of snow at the South Pole, J. Glaciol., 5(40), 467-477, 1965.

Hammer, C. U., H. B. Clausen, W. Dansgaard, N. Gundestrup, S. J. Johnsen, and N. Reeh, Dating of Greenland ice core by flow models isotopes, volcanic debris, and continental dust, $J$. Glaciol., 20(82), 3-26, 1978.

Johnsen, S. J., Stable isotope homogeneisation of polar firn and ice, IAHS-AISH Publ., 118, 210-219, 1977.

Jouzel, J., L. Merlivat, M. Pourchet, and C. Lorius, A continuous record of artificial tritium fallout at the South Pole, Earth Planet. Sci. Lett., 45, 188-200, 1979.

Koemer, R. M., A stratigraphic method of determining the snow accumulation rate at Plateau Station, Antarctica, and application to South Pole-Queen Maud Land Traverse 2, 1965-1966, in Antarctic Snow and Ice Studies II, vol. 16, edited by A. P. Crary, pp. 225-238, AGU, Washington, D. C., 1971.

Lambert, G., J. R. Petit, M. Pourchet, J. Sanak, and C. Lorius, Variations récentes de l'accumulation de la neige sur la calotte Antarctique, paper presented at International Conference on Evolution of Planetary Atmospheres and Climatology of the Earth, Centre Natl. d'Etudes Spatiales, (France), Nice, Oct. 1620, 1978.

Lorius, C., and L. Merlivat, Distribution of mean surface stable isotope value in East Antarctica: Observed changes with depth in the coastal area, IAHS-AISH Publ., 118, 127-137, 1977.

Lorius, C., L. Merlivat, J. Jouzel, and M. Pourchet, A 30,000 year 
isotope climatic record from Antarctic ice, Nature, 280 (5724), 644-648, 1979.

Merlivat, L., J. Jouzel, J. Robert, and C. Lorius, Distribution of artificial tritium in firn samples from East Antarctica, IAHS-AISH Publ., 118, 138-145, 1977.

Merlivat, L., J. Jouzel, J. R. Petit, and C. Lorius, Climatic information over the last century deduced from a detailed isotopic record in the South Pole snow, paper presented at XVIIth General Assembly, Int. Assoc. of Atmos. Phys., Canberra, Australia, Dec. 2-15, 1979.

Picciotto, E., and S. Wilgain, Fission products in Antarctic snow, a reference level for measuring accumulation, J. Geophys. Res., 68 , 5965-5972, 1963.

Picciotto, E., G. Crozaz, and W. De Breuk, Accumulation on the South Pole-Queen Maud Land Traverse, 1964-1968, in Antarctic Snow and Ice Studies $I I$, vol. 16, edited by A. P. Crary, pp. 257315, AGU, Washington, D. C., 1971.
Pourchet, M., F. Pinglot, and C. Lorius, Some meteorological application of radioactive fallout measurements in Antarctic snows, paper presented at XVIIth General Assembly, Int. Assoc. of Atmos. Phys., Canberra, Australia, Dec. 2-15, 1979.

Sanak, J., and G. Lambert, Lead 210 or climatic changes at South Pole?, Geophys. Res. Lett., 4, 357-359, 1977.

Taylor, C. B., A comparison of tritium and strontium-90 fallout in the southern hemisphere, Tellus, 20, 569-576, 1968.

Whillans, I. M., Surface mass-balance variability near "Byrd Station", Antarctica, and its importance to ice core stratigraphy, $J$. Glaciol., 20(83), 301-310, 1978.

(Received September 11, 1980; revised April 15, 1981; accepted April 22, 1981.) 